\title{
Definition of Debt on PT. Telekomunikasi Selular's Banktruptcy Case
}

\author{
Christian Victor Koemolontang \\ \{koemolontang1@gmail.com\} \\ Universitas 17 Agustus 1945 Jakarta, Jakarta, Indonesia
}

\begin{abstract}
PT. Telekomunikasi Selular signed an agreement with PT. Prima Jaya Informatika, whereby it gave the right to the latter to sell its pre-paid vouchers. Afterward, PT. Prima Jaya Informatika sent two purchase orders valued at IDR 5.6 billions. Those purchase orders were rejected and PT. Prima Jaya Informatika filed a bankruptcy petition against PT. Telekomunikasi Selular. The aim of this research is to determine whether PT. Telekomunikasi Selular had debts to PT. Prima Jaya Informatika. This research is a normative legal research and also a case study research. Using both primary and secondary data obtained mainly through library research and interviews. Analysis was conducted using qualitative approach with comparative perspective. Discussion's results showed that PT. Telekomunikasi Selular did not have any debts to PT. Prima Jaya Informatika as the latter had not paid the purchase orders. Therefore the existance of debt was very difficult to prove.
\end{abstract}

Keywords: debt, bankruptcy, commercial court

\section{Introduction}

Current business practices always involving debts between business parties in its daily trans actions. Debt is commonly used by businesses as a financial tool to leverage its financial capacity and flexibility. Most common debts are in forms of banks' loan, both long term debt and short term debt, and also debt that being raised from capital market. Other form of common debt is vendors' financing which is recorded as account payables and/or account receivables on the balance sheet.

Debts in daily business transactions are formalized in forms of loan agreements between creditors and debtors under Indonesian civil law. Loan agreement regulates the rights and obligation s of both parties, creditors and debtors. Failure of one of the parties or both parties to fulfill its obligation will create an event of default and outstanding debts. Unpaid debts can be used as basis to submit bankruptcy petition to commercial court under Indonesian Bankruptcy Law [1].

Indonesian Bankruptcy Law regulates three basic requirements as the basis for a bankruptcy petition:(1) there is at least a valid debt that already due and collectable that is not paid in full/on time, (2) there are two or more creditors, and (3) both legal states aboved can be easily proven. Hence, existance of debt is a very important matter in any bankruptcy case 
and law regulates that it has to be easy to be proven before it can be brought to commercial court.

Debt itself can be described as any liabilities that can be defined in terms of Indonesian currency or any foreign currencies, that arises or will arise as consequences of agreement or law and has to be fulfilled by debtors and if not will give rights to creditors to obtain the fulfillment from debtors' as sets.

Jerry Hoff defines debt in a broader perpectives, he defines debt as general obligations that have to be performed by debtors. This relates to Article 1233 and 1234 of Indonesian Civil Code [2]. Further, Hoff describes bannkruptcy as a general statutory attachment encompassing all the assets of the debtors. Bankruptcy is a legal state that determined by commercial court upon an approval of a banckruptcy petition submitted by one or more creditors.

PT. Telekomunikasi Selular (Telkomsel) is one of the leading mobile phone networks provider in Indonesia and majority owned by Government of Indonesia. It provides two types of mobile services, the post paid and the pre-paid services. The pre-paid service comes in form of pre-paid SIM card that being dis tributed through the company's distribution channel and also through cooperation with several priv ate companies.

The bankruptcy case of Telkoms el was complicated and became controversial in the sense that it was not caused by an act of default under a loan agreement, rather it was due to a default of a pre-paid vouchers' dis tribution cooperation agreement. At the time Telkoms el was declared bankrupt by commercial court, it had a total as sets of IDR 48.7 trillion and a net profit of IDR 3.5 trillion, a very strong financial condition compared to the amount of IDR 5.6 billion that being disputed.

Telkomsel signed an agreement with PT. Prima Jaya Informatika where both parties entered into an agreement to distribute a sport theme pre-paid SIM cards and vouchers. A hybrid business model of business initiative and corporate social res ponsibility program of Telkomsel to support Indonesian sportmen led Telkomsel to sign an agreement with PT. Prima Jaya Informatika.

The two-year agreement was signed on 1 June 2011 where PT. Prima Jaya Informatika was assigned to sell 10 million SIM cards and 120 million vouchers within one year time. At the end of the first year of the agreement, PT. Prima Jaya Informatika did not able to sell the amount assigned by Telkomsel, it only managed to sell about 525,000 SIM cards and 1.9 million vouchers.

On the date of 20 June 2012 or after the first one year time lapsed, PT. Prima Jaya Informatika sent a purchase order amounting IDR 2.6 billion and another purchase order on 21 June 2012 amounting IDR 3 billions. The first purchase order was rejected by Telkomsel on 21 June 2012 through electronic mail.Telkomsel also rejected the second purchase order through electronic mail.

PT. Prima Jaya Informatika considered the rejection as an event of default performed by Telkomsel and creating a valid debt that was due and collectible. The plaintiff also able to verify that Telkomsel had another unpaid debt to PT. Extend Media Indonesia with the 
amount of IDR 40 billions. PT. Prima Jay a Informatika filed bankruptcy petition against PT. Telekomunikasi Selular (Telkomsel) to Central Jakarta Commercial Court. On 14 September 2012, The Panel of Judges at Commercial Court accepted the petition and declared Telkomsel into bankruptcy.

The Telkoms el's bankruptcy case is a very interesting legal case. The existance of debt in this case will be discussed in the following chapter. Telkomsel case showed that Indonesia Bankruptcy Law does not take into consideration the financial state of the debtors. It only take legalstate of the debtors and focus on the three basic requirements of bankruptcy (unpaid debts, two or more creditors, simple proof).

\section{Purpose}

To determine the definition of debt in the bankruptcy case of PT. Telekomunikasi Selular and evaluate whether the mentioned debt was valid, due and collectible. To evaluate the legal considerations of the Panel of Judges of Commercial Court when deciding to grant the bankruptcy petition summonned by PT. Prima Jaya Informatika.

The results of this study also expected to contribute a legal knowledge to legal communities, both students and practioners, especially in the field of bankruptcy law. It also expected to give contributions to business sectors who deals with debts on daily basis when running their businesses.

\section{Method}

The method used in this paper is a normative juridical research method with focus on conducting juridical studies on bankruptcy in particular on the existance of debts, events of defaults, unpaid debts, and bankruptcy procedures in the commercial court [3]. To achieve the above purpose, literature study is used, using legal material to answer the problem formulation. The legal materials include court decisions, laws and regulations, doctrines and supporting literature that be divided into primary, secondary and tertiary legal materials.

This paper uses a normative-empirical leg al research approach by doing an abstraction of the process of deduction from the prevailing positive legal norms, namely examining the law as a positive norm using deductive thinking and combined with judicial case study.

The data intended in this study are materials or facts or may also be interpreted as a source of information. While the legal material intended in this study consists of primary legal material and secondary legal material. Primary legal material is an authoritative legal material which means that it has regulatory authority, minutes or official records, court decisions and also direct interviews with bankruptcy law experts. Whereas what is meant by secondary legal materials are books (expert opinion), journals, and everything that can provide guidance for researcher.

The data obtained are analyzed so that rational reasons can be found regarding the formulation of the problemand its analysis. The results of the processing are analyzed and then discussion conducted and conclusions drawn. 


\section{Result and Discussion}

\subsection{Result}

Debt that occured in case of Telkoms el was arise due to Telkoms el's failure to deliver prepaid SIM cards and vouchers as ordered by PT. Prima Jay a Informatika under the distribution cooperation agreement. Debt in this case is in line with the definition from several legal expert such as Hoff, Mulyadi, and Sjahdeini who all refer to Article 1233 and 1234 Indonesian Civil Code.

The failure of Telkomsel to deliver pre-paid SIM cards and vouchers to PT. Prima Jaya Informatika was an event of default that created a valid debt, due and collectible. Expert witnes s als o considered pre-paid SIM cards and vouchers have a monetary value just like currency, so can be considered as proxi money and has monetary value.

It also proven that Telkomsel had an unpaid debt to other creditor, PT. Extend Media Indonesia, therefore the second requirement of having at least two creditors also had been fulfilled.

The panel of judges at commercial court also decided that the debt can be proven in a simple method, thus all three basic requirements to accept the bankcruptcy petition all had been fulfilled and gave a strongjustification for the panel of judges to accept the bankruptcy petition.

The panel of judges dis mis sed all the exception s brought forward by Telkoms el's lawyers that the purcase orders had notbeen paid for by PT. Prima Jaya Informatika and also the fact that PT. Prima Jaya Informatika had defaulted prior to give the purchase orders. The obligation to sell 10 million pre-paid SIM cards and 120 million vouchers did not fulfilled by the plaintiff.

\subsection{Discussion}

Purchase orders that is sued by PT. Prima Jaya Informatika acted as evidence of the debt. Being the significantevidence of even of defaults that created unpaid debt, these purchase orders hold very important position in legal views.

The generally accepted definition of purchase order is it is a buyer-generated document that authorized a purchase transaction, where when accpeted by the seller will become a legally binding contracts for both parties [4]. Usually a purchase order contains goods/services' descriptions, quantities, price, discount, payment terms, shipment, and a specific seller's name.

Gunawan Widjaja [5], in his expert testimony mentioned that the payment terms on the purchase orders is sued by PT. Prima Jay a Informatika were ruled in the agreement. PT. Prima Jaya Informatika had to pay the amount that they ordered within seven caledar days after is suing the purchase order. Given the fact that the payment had never been made according to contract while purchase orders had been is sued, it resulted a totally different legal facts. 
If that was the case, then PT. Prima Jaya Informatika was the party that had the debt or became the debtor, since it never paid the purchase orders and Telkoms el was the creditor. In this case, the panel of judges at commercial court should have rejected the bankruptcy petition.

Other is sue that evolved in this legal case was the principle of simple evidence of debt. Having mentioned the default of PT. Prima Jaya Informatika to pay the purchase orders, Telkomsel also brought the fact that PT. Prima Jaya Informatika had defaulted on its obligation to sell a certain amount of pre-paid SIM cards and vouchers within the one year time frame or prior to the release of the purchase orders.

The process of proofing the existance of debt was very difficult in case of Telkomsel against Prima Jaya Informatika, therefore this case should not be accepted by commercial court. The existance of debt either by both parties had to be proven in front of a distric court.

The Indonesian Bankruptcy Law has two major problems: it does not take financial condition of the debtors into consideration and the principle of simple evidence of debts and number of creditors.

In other countries, bankruptcy is the last option available in legal system to solve debts. Both persons and companies might face insolvency from time to time, either cash flows insolvency or balance sheet insolvency. Yet, the spirit of bankruptcy law is to seek the best solution for debtors that cannot pay their debts to creditors. Bankruptcy law provides protection for both parties, creditors and debtors. If we look at the United States Bankruptcy Code, the famous Chapter 11 is called Reorganization. It is a court-approved reorganization plan that submitted by debtors with main objective to pay its debts to creditors.

When comparing US Bankruptcy Code with Indonesian Bankruptcy Law, it is obvious that the two has different objectives [6]. While the US Bankruptcy Code accomodate reorganization by debtors so it can pay their debts in the future, the Indonesian version is focusing itself on seizing the debtors' assets as the only way to repay their debts.

The Indonesian Bankruptcy Law also does not take into consideration the financial condition of the debtors. In example of Telkomsel, a company with a total aasets of IDR 48.7 trillion was declared bankrupt due to a debt of IDR 5.6 billion (roughly about $0.011 \%$ ). This legal situation put Indonesia into difficult position to attract more foreign direct investment as there is barely no protection frombankruptcy treats.

The second major is sue is the simple method of proofing the evidence of debt and at least two creditors. Although the original objectives of this simple proof method is understandable given the economic cris is that hit Indonesia and South East Asia in 1998, this principle has created a lot of legal problems.

A lot of bankruptcy cases involving complicated forms of debts especially in a sophisticated loan agreement or the ones that involving derivatives financial transactions. Even in the case of Telkomsel, an unpaid purchase orders from a distribution cooperation agreement resulting a complicated debt. 
The power own by the panel of judges at commercial court when deciding a debt as a simple to proof or difficult to proof sometimes become bias and creating legal uncertainties for parties that involved.

\section{Conclusion}

Definition of debt in the case of PT. Telekomunikasi Selaluar's bankruptcy case is a failure to deliver goods that being ordered by a buyer.

With reference being made to Indonesian Civil Code, a failure as such indeed creating a debt that is valid, due, and collectible. Unwillingness to pay such debt, combined with existance of at least another creditor, faced the party to risk of being declared bankrupt by commercial law.

The fact that the purchase orders had not been paid yet and creating confusion who actually the debtor was, should had been taken into consideration by the panel of judges. Having said that, the finaldecision of the panel of judges at commercial court was final and had to be respected.

And also to be concluded that Indonesian Bankruptcy Law does not take into consideration the financial condition of debtors, even a financially healthy companies always faced the risk to be declared bankrupt as long as the three basic requirements are met. Finally, the simple proof method has been creating a lot of legal is sues so far. It is time to improve the Indonesian Bankruptcy Law and make it as a main pilar for justice for both debtors and creditors.

\section{References}

[1] Ginting, Elyta Ras, Bankruptcy Law, Bankruptcy Theory. Sinar Grafika, 2018, 5.

[2] Sjahdeini, Sutan Remy, History, Principles, Theory, Bankruptcy Law. Prenada Media Group, 2016, 187.

[3] Soekanto, Soerjono, Introduction to Law Research. Jakarta: UI Press, 1981, 43.

[4] Downloaded from http://www.businessdictionary.com on 5 January 2020.

[5] Interview with Gunawan Widjaja, expert witness on the case of Telkomsel against Prima Jaya Informatika, on 21 December 2019.

[6] David G. Eipstein, Bankruptcy. St. Paul Minn: West Publishing Co. 1995, 4. 